\section{Impact of Microabrasion on the Effectiveness of Tooth Bleaching}

\author{
Camila Evelyn Perete-de-Freitas, Paula Damasceno Silva, André Luis Faria- \\ e-Silva
}

Department of Dentistry, UFSE - Universidade Federal de Sergipe, Aracaju, SE, Brazil

Correspondence: André Luis Faria e Silva

Rua Cláudio Batista, s/n, 49060100 Sanatório, Aracaju, SE, Brazil. Tel:+55-79-2105-1821. e-mail: fariaesilva.andre@gmail.com
The aim of the present study was to evaluate the effect of prior microabrasion on the teeth color change and tooth bleaching effectiveness. Eight sound molars were mesiodistally sectioned and the halves were randomly allocated to receive enamel microabrasion or non-abrasion (control) in one of surfaces (buccal or lingual), while the remaining surface received the other treatment. The tooth color on baseline was evaluated by spectrophotometer (CieL*a*b system). After the microabrasion procedure, the tooth color was measured again. Following, the specimens were bleached with 35\% hydrogen peroxide for two sessions with one-week interval. The color was re-evaluated 7 days after each section and 30 days after the second session. The effect of enamel microabrasion on color changes was evaluated by paired T-test. Deltas $L^{*}, a^{*}, b^{*}$, and $E$ were calculated and data submitted to 2-way repeated measure ANOVA followed by Tukey's test. Paired T-test was also used to assess possible differences on the ultimate color achieved after tooth bleaching. Enamel microabrasion reduced the lightness and increased the redness of specimens. Specimens that received microabrasion presented higher values of $\Delta \mathrm{L}^{*}$ than control after each bleaching procedure; and higher $\Delta \mathrm{a}^{*}$ after the $2^{\text {nd }}$ bleaching session. However, the prior enamel microabrasion did not affect the ultimate values of color parameters. Despite enamel microabrasion have modified the tooth color, this procedure did not affect the ultimate results achieved with tooth bleaching using a high-concentrated hydrogen peroxide.

\author{
Key Words: Enamel \\ microabrasion, tooth bleaching, \\ tooth discoloration.
}

\section{Introduction}

Tooth discoloration is usually treated with restorative procedures or using more conservative approaches such as tooth bleaching approaches $(1,2)$. The tooth bleaching techniques performed either in office or by patients at home are carried out using bleaching agents based on hydrogen or carbamide peroxides (3-5). The bleaching effect is achieved due to oxidative action of peroxides and its sub-products on the organic matrix of the tooth tissues modifying its optical properties $(6,7)$. Despite the high success rates observed for both in-office and athome bleaching procedures $(4,5)$, using oxidative agents are unable to solve aesthetic alterations of teeth when the discoloration is intrinsic in the enamel due to fluorosis staining and other enamel hypoplasia, or white lesion spot caused by dental caries $(8,9)$.

In the presence of the enamel alterations, the superficial enamel removal by abrasive product associated to acid etching using the so-called enamel microabrasion is frequently carried out by clinicians to solve tooth discolorations limited to enamel (10-13). The enamel microabrasion procedure is performed by active application of a paste containing an acid (usually phosphoric or hydrochloric), which demineralizes the superficial layers of enamel, and an abrasive such as silicon carbide or pumice to remove the demineralized enamel $(11,12)$. The rationale is to remove the affected outer layer, preserving the unaltered inner enamel. Therefore, the success of enamel microabrasion depends on the depth of enamel alteration. Moreover, the partial removal of enamel within reduction on its thickness increases the light transmission through of enamel, allowing an increased perception of dentin $(12,14)$. Thus, it is expected darker color of teeth submitted to microabrasion due to thinner enamel, similarly to darkening observed on cervical area or by ageing of teeth.

Despite the possible effect the enamel microabrasion on color modification, few studies are found evaluating this outcome following microabrasion procedures. Furthermore, considering a possible tooth darkening due to microabrasion, tooth bleaching procedures using peroxides might be required following the abrasive procedure to reach proper esthetic $(15,16)$. Considering that changes in the enamel caused by tooth bleaching have important role on the ultimate color achieve with this esthetic procedure $(17,18)$, it is important to know about any possible effect of alteration caused in the enamel by microabrasion on efficacy of posterior tooth bleaching. However, to the best of our knowledge, there is no study evaluating the effect of prior enamel microabrasion on effectiveness of following tooth bleaching. Thus, this study aimed to evaluate the color alteration on tooth caused by enamel microabrasion as well its effect on effectiveness of following 
tooth bleaching. The null hypotheses tested were that 1) the enamel microabrasion does not intervene on the tooth color; and 2) the tooth bleaching was not affected by prior enamel microabrasion.

\section{Material and Methods}

\section{Experimental Design}

Hemi-sections of sound molars were submitted to microabrasion, while the opposite hemi-section of the same tooth was used as control. Following, all hemi-sections were submitted to two sessions of tooth bleaching with 35\% hydrogen peroxide. The color changes were evaluated using the parameters $L^{*}, a^{*}$, and $b^{*}$. The effect of microabrasion on these parameters was analyzed as well as the bleaching effects on color changes regarding to time of assessment in three-levels (after each session and 30 days after the last session) and prior enamel microabrasion in two levels (absent or present).

\section{Sample Preparation and Randomization}

Eight sound third molars without cracks or fractures were selected for the study. The molars were sectioned using a diamond saw coupled to a hand-piece on cementenamel junction; and the roots were excluded. Following, the crowns were mesio-distally sectioned in two halves containing the buccal or lingual enamel surface. For each molar, one hemi-section was randomly allocated to receive enamel microabrasion, while the other one was used as control for this procedure. The randomization was carried out using a randomized list created using a webpage www. sealedenvelope.com.

\section{Baseline Measurements}

Baseline color measurements of all specimens were carried-out using a spectrophotometer SP60 (X-Rite, Grand Rapids, MI, USA) based on the Commission Internationale de I'Eclairage (CIE) L*a*b system. The readings were performed under a white background during the entire experiment, while the values of parameters $L^{*}, a^{*}$ and $b^{*}$ were recorded.

\section{Microabrasion Procedures}

For the hemi-sections allocated to be submitted to enamel microabrasion, the procedure was performed using $6.6 \% \mathrm{HCl}$ slurry with silicone carbide micro-particles (Opalustre, Ultradent Products, Inc., South Jordan, UT, USA). The buccal/ lingual enamel was air-dried and a small amount of abrasive slurry was applied over the enamel with a rubber cup attached to hand-piece for 60 seconds under low rotation. After remove the abrasive and dry the enamel, the procedure was repeated until to complete 10 applications. After the enamel microabrasion, the color measurements were performed again and the specimens were stored for $24 \mathrm{~h}$ under 100\% of humidity.

\section{Tooth Bleaching}

The bleaching agent based on 35\% hydrogen peroxide (HP Whiteness Maxx, FGM, Joinville, SC, Brazil) was manipulated according to manufacturer's recommendation and applied over the enamel surface of all specimens, remaining for 15 minutes. After this time, the bleaching agent over the surface was replaced to totalize 3 applications (45 minutes). Then, the bleaching agent was completely removed using water-stream, and the specimens stored in distilled water for one week. After this period, the color of the specimens was again measured and a second bleaching session performed, following the procedures described previously. The bleached specimens were stored in distilled water and further color measurements carriedout after 7 and 30 days from the second bleaching session. For each time of assessment, color changes were measured by $\Delta \mathrm{L}^{*}, \Delta \mathrm{a}^{*}$ and $\Delta \mathrm{b}^{*}$ calculation based on data measured at baseline or after the microabrasion for teeth from control and abraded, respectively. Delta $E$ was calculated by following equation: $\Delta \mathrm{E}=\left[(\Delta \mathrm{L})^{2}+(\Delta \mathrm{a})^{2}+(\Delta \mathrm{b})^{2}\right]^{1 / 2}$.

\section{Statistical Analysis}

In order to evaluate the effect of the microabrasion on color changes, data (before and after) of $\mathrm{L}^{*}, \mathrm{a}^{*}$ and $\mathrm{b}^{*}$ from specimens submitted to paired T-test. In order to assess the bleaching effectiveness, data from color changes $\left(\Delta \mathrm{L}^{*}, \Delta \mathrm{a}^{*}\right.$, $\Delta \mathrm{b}^{*}$ and $\Delta \mathrm{E}$ ) were individually submitted to 2-way repeated measure ANOVA ("time of assessment" as repetition factor) followed by Tukey's post hoc test. Paired T-tests were used to assess differences on color parameters at baseline and final between the specimens allocated to receive or not enamel microabrasion. A significance level of $95 \%$ was set for all statistical analyses.

\section{Results}

Table 1 shows the changes on color parameters caused by enamel microabrasion. The microabrasion reduced the lightness and increased the redness of teeth, did not affecting the parameter $b^{*}$. Table 2 presents the color changes following the bleaching procedures. Regarding $\Delta L^{*}, 2$-way Repeated measured ANOVA showed that both the "moment of assessment" $(p<0.001)$ and "prior microabrasion" ( $p=0.044)$ affected the tooth lightness, whereas the interaction was not significant $(p=0.491)$. Reduced alteration on lightness was observed after the $1^{\text {st }}$ session and the highest lightness changes were found 30 days after the second session, irrespective to perform or not prior microabrasion. For all times of assessment, specimens submitted to enamel microabrasion presented higher lightness changes. Data of $\Delta \mathrm{a}^{*}$ were affected by the "time of assessment" $(p<0.001)$, whereas the "prior 
microabrasion" alone $(p=0.063)$ was not significant but intervene on data ( $p$-value for interaction $=0.037$ ). Irrespective to performing enamel microabrasion, lowest $\Delta \mathrm{a}^{*}$ values were observed after the $1^{\text {st }}$ session without difference between the other times of assessment. The prior microabrasion affected the $\Delta \mathrm{a}^{*}$ only on evaluation performed 7 days after the $2^{\text {nd }}$ session, when abraded teeth presented the highest values. For $\Delta b^{*}$, only the "time of assessment" $(p<0.001)$ intervene on results, while the "prior microabrasion" $(p=0.755)$ and the interaction between the factors ( $p=0.187$ ) were not significant. Highest reduction on yellowness was observed 30 days after the $2^{\text {nd }}$ session of tooth bleaching, while no difference was observed between the other "times of assessment". Statistical analysis of data from $\Delta \mathrm{E}$ also indicated that only the "times of assessment" $(p<0.001)$ affected the pooled color change, while the prior enamel microabrasion $(p=0.350$; for interaction, $p$ $=0.838$ ) does not modify the $\Delta \mathrm{E}$ values. Highest color changes were observed 30 days after the last bleaching session without difference between the other times.

Figure 1 illustrates the behavior of color parameters during the entire experiment for both control and abraded teeth. The paired T-tests demonstrated that the prior microabrasion did not intervene on color parameters observed in the final of the experiment and that there was no difference on tooth color of specimens on baseline.

\section{Discussion}

The enamel microabrasion is a usually conservative aesthetic procedure used to treat spot lesions restricted to enamel tissue such as hypoplasia or white spot lesion caused by dental caries. ${ }^{9-13}$ Corroborating with the clinical observations, the enamel removal by microabrasion affected

Table 1. Means (standard deviation) for each color parameter changes following the enamel microabrasion procedure $(n=8)$

\begin{tabular}{lccc}
\hline \multirow{2}{*}{$\begin{array}{l}\text { Time of } \\
\text { assessment }\end{array}$} & \multicolumn{3}{c}{ Color parameter } \\
\cline { 2 - 4 } & $\mathrm{L}^{*}$ & $\mathrm{a}^{*}$ & $\mathrm{~b}^{*}$ \\
\hline Baseline & $87.5(1.8)$ & $2.5(0.8)$ & $10.3(2.8)$ \\
After microabrasion & $85.8(1.7)$ & $3.1(1.0)$ & $10.8(4.3)$ \\
p-value* & 0.001 & 0.032 & 0.706 \\
\hline
\end{tabular}

*Calculated by paired t-test. the tooth color, rejecting the first null hypothesis of study. The lightness $\left(\mathrm{L}^{*}\right)$ of teeth was reduced and redness $\left(\mathrm{a}^{*}\right)$ increased by the abrasive procedure. This color changes due to erosive ability of the slurry rubbed over the enamel. Despite the thickness modification of enamel was not measured in the present study, it is expected an enamel thickness reduction ranging to 25 to $200 \mu \mathrm{m}$ due to microabrasion (19). A thinner enamel allows higher light transmission through of this tissue, increasing the visualization of underlay dentin and reducing the lightness and increasing the redness (14).

Once that the patients are frequently requiring whiter teeth, the reduction on lightness and increased redness caused by enamel microabrasion might require an additional aesthetic intervention, while the tooth bleaching is the more conservative approach $(15,16)$. In the present study a high-concentrated hydrogen peroxide based bleaching agent was used simulating an in-office tooth bleaching procedure. Despite the at-home bleaching agents are largely used by patients with successful, the in-office bleaching still recommended for some clinical situations including patients presenting gingival recession, gastric disorders, or reduced salivary flowing (20-22). Moreover, using an in-office bleaching agent with hydrogen peroxide activation by its mixing with the thickener facilitates the experimental protocol reducing bias when compared to athome products, while the peroxide activation depends on $\mathrm{pH}$ buffering by saliva (23). The action mechanism of bleaching agents is related to oxy-reduction reaction of peroxides within stain molecules located in the organic matrix, while these molecules become simpler and whiter $(6,7)$. The results of the presents study found that the bleaching effect was mainly related to changes on lightness $\left(\mathrm{L}^{*}\right)$ and redness $\left(a^{*}\right)$, while slight alteration on yellowness was observed. Teeth submitted to prior microabrasion presented higher values of $\Delta \mathrm{L}^{*}$ than those observed for specimens from control condition at all times of assessment. These results can be explained due to differences at color presented by specimens prior to tooth bleaching, while the teeth submitted to microabrasion presented reduced lightness. It has been demonstrated that the bleaching effect is

Table 2. Means (standard deviation) of changes on color parameters following the bleaching procedures $(\mathrm{n}=8)$

\begin{tabular}{|c|c|c|c|c|c|c|c|c|}
\hline \multirow{3}{*}{$\begin{array}{l}\text { Time of } \\
\text { assessment }\end{array}$} & \multicolumn{8}{|c|}{ Deltas from baseline measurement } \\
\hline & \multicolumn{2}{|c|}{$\mathrm{L}^{*}$} & \multicolumn{2}{|c|}{$a^{*}$} & \multicolumn{2}{|c|}{$b^{*}$} & \multicolumn{2}{|c|}{$\mathrm{E}$} \\
\hline & Control & Abraded & Control & Abraded & Control & Abraded & Control & Abraded \\
\hline After $1^{\text {st }}$ session & $1.3(1.0)^{\mathrm{Bc}}$ & $2.3(1.2) \mathrm{Ac}$ & $-1.1(0.4)^{\mathrm{Ab}}$ & $-1.4(0.5)^{\mathrm{Ab}}$ & $-2.0(2.0) \mathrm{Ab}$ & $-0.7(4.7)^{\mathrm{Ab}}$ & $3.1(1.5) \mathrm{Ac}$ & $4.9(2.2) \mathrm{Ac}$ \\
\hline After $2^{\text {nd }}$ session & $2.9(1.3)^{\mathrm{Bb}}$ & $3.8(1.4)^{\mathrm{Ab}}$ & $-1.7(0.7)^{\mathrm{Ba}}$ & $-2.4(0.7)^{\mathrm{Aa}}$ & $-1.3(3.0) \mathrm{Ab}$ & $-1.3(4.6)^{\mathrm{Ab}}$ & $4.7(1.0)^{\mathrm{Ab}}$ & $6.1(2.3)^{\mathrm{Ab}}$ \\
\hline Final & $4.4(1.7)^{\mathrm{Ba}}$ & $5.7(1.7) \mathrm{Aa}$ & $-2.0(0.5)$ Аа & $-2.4(0.6)$ Аа & $-4.5(2.2)$ Аа & $-4.4(4.5) \mathrm{Aa}$ & $6.8(1.9) \mathrm{Aa}$ & $8.5(2.7) \mathrm{Aa}$ \\
\hline
\end{tabular}

Different letters (uppercase for rows, lowercase for columns) indicate statistically significant difference $(\mathrm{p}<0.05)$ 
limited and usually more pronounced when carried out in darker teeth (4). This fact also explains the higher changes on parameter $\mathrm{a}^{*}$ observed for abraded teeth following the

A

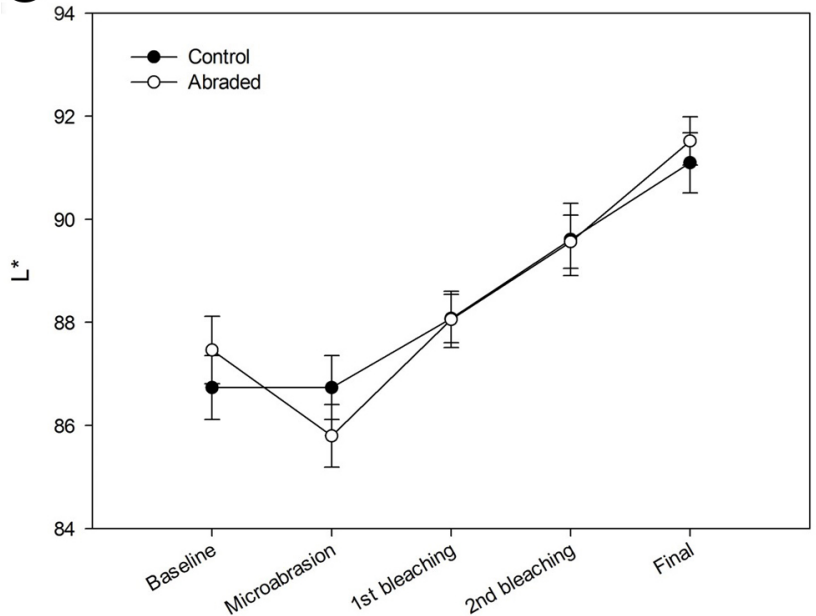

C

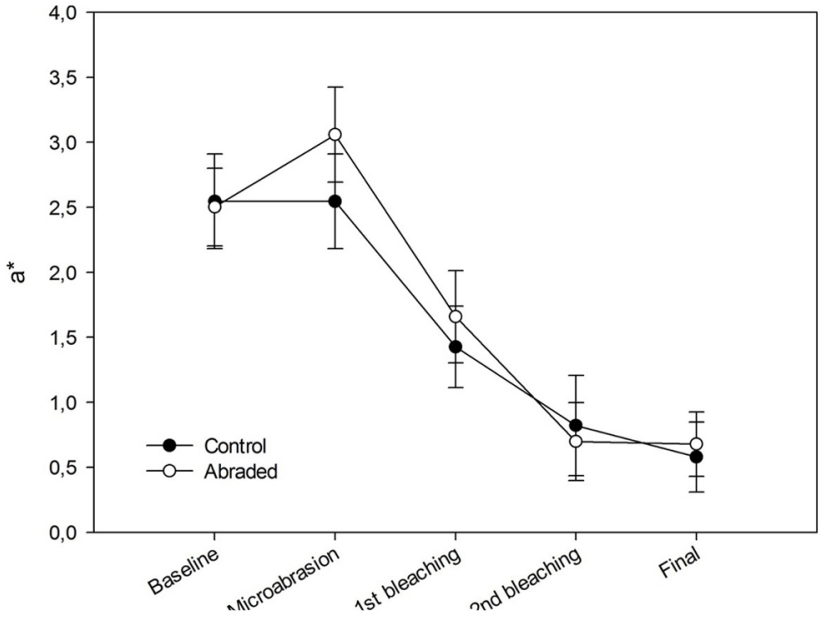

E

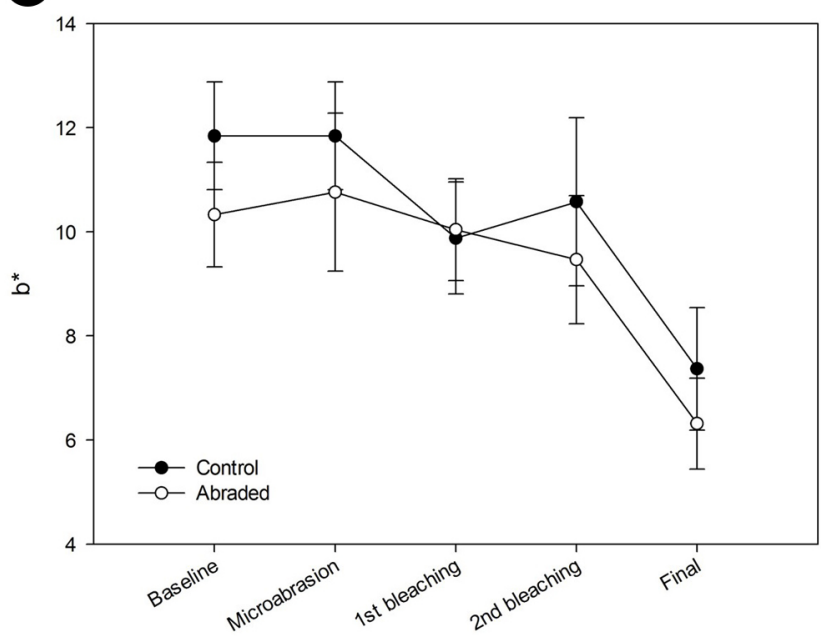

$2^{\text {nd }}$ session of tooth bleaching.

Beside to the differences on color change following the bleaching procedures, the results of the present study

B

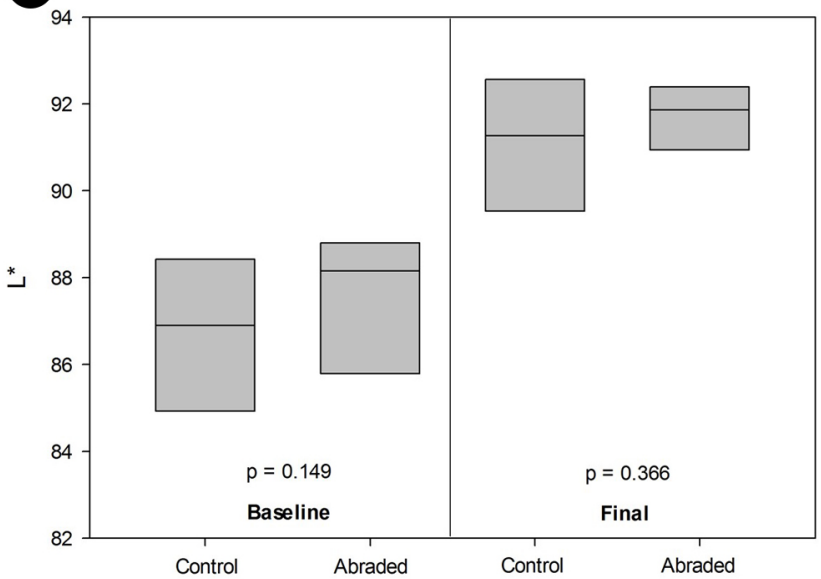

(D)

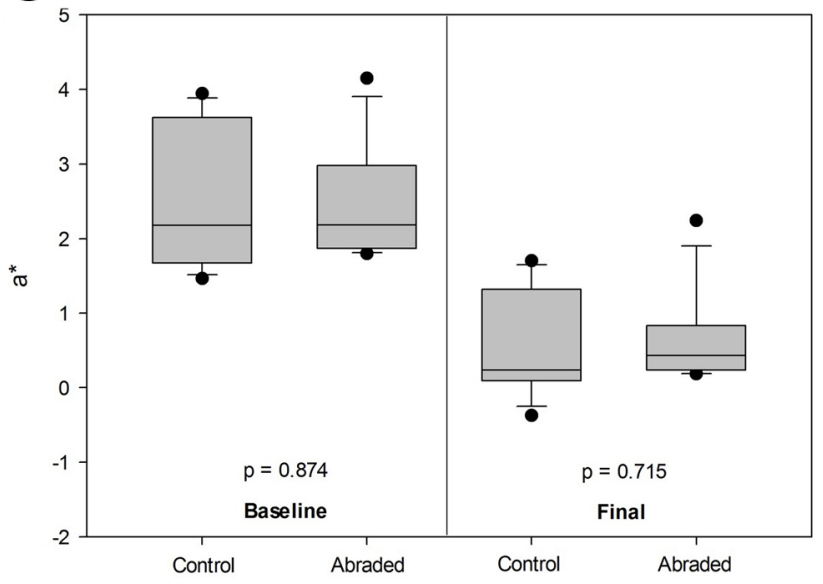

F

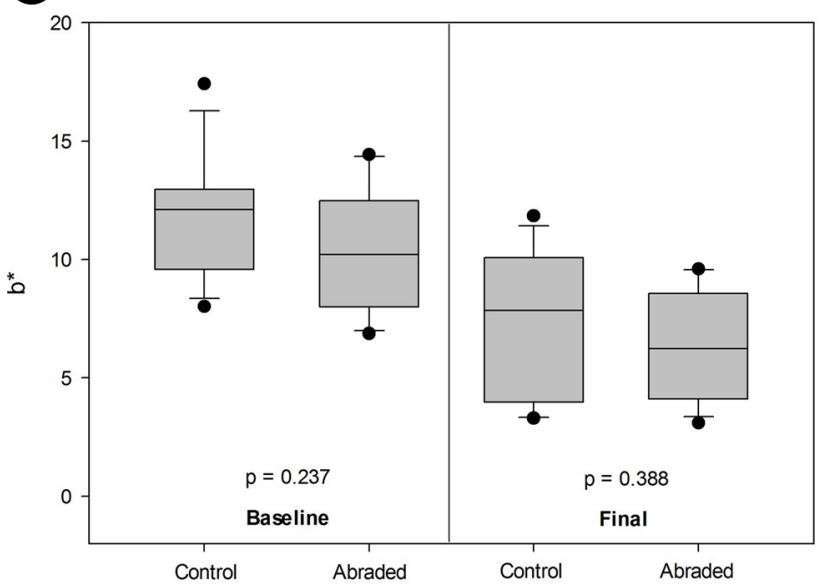

Figure 1. Behavior of color parameters $\left(\mathrm{L}^{*}-\mathrm{A} ; \mathrm{a}^{*}-\mathrm{C}\right.$; and $\left.\mathrm{b}^{*}-\mathrm{E}\right)$ during the experiment according to presence or absence of prior microabrasion; and comparison between the color parameters $\left(\mathrm{L}^{*}-\mathrm{B} ; \mathrm{a}^{*}-\mathrm{D}\right.$; and $\left.\mathrm{b}^{*}-\mathrm{F}\right)$ at baseline and at final of experiment from teeth allocated to receive or not microabrasion. Bars indicate standard error. 
demonstrated that the prior microabrasion did not affect the ultimate color achieved by tooth bleaching with hydrogen peroxide. Thus, the second hypothesis was accepted. In fact, the values of all color parameters were similar at the last assessment. It is reasonable to think that slower bleaching could occurs for the abraded teeth due to darker color due to prior microabrasion. However, the results demonstrated similar color (absence on difference for all color parameter) between the abraded and control specimens after the $1^{\text {st }}$ session of tooth bleaching. Moreover, additional bleaching effect was achieved with the $2^{\text {nd }}$ session and within the 30 days following this last peroxide application. This last change color was mainly related to increasing on lightness and reduction on yellowness, whereas the no significant modification on redness was observed. The measurement of color after 30 days was chosen to determine any residual effect of tooth bleaching and to simulate clinical conditions when a rebound effect has been demonstrated $(3,24)$. The rebound effect tends to slight reduce the effect reached by tooth bleaching and is mainly due to physiological response to pulpal damage. On the other hand, this effect is not expected using ex-vivo teeth and the color changes following the storage time might be associated to any possible residual effect of peroxide remaining in the hard tooth tissue $(25,26)$. It is hypothesized that the absence of pulpal pressure in extracted teeth can reduce the removal of peroxide and its products, mainly than located inside the dentinal tubules; while these components can produce additional bleaching effect (27).

The outcomes of the present study demonstrated that the enamel microabrasion did not affect the bleaching effectiveness, despite to reduce the lightness and increase the redness of teeth. One important limitation of method used was that teeth without any enamel discoloration (i.e. fluorosis, white spot lesion) were used. Further to facility to obtain specimens, using teeth without any enamel discoloration helps to standardize the baseline measurement. However, it is difficult to determine if the enamel removal by microabrasion techniques performed would be enough to eliminate any kind of enamel alteration. Moreover, measuring the enamel thickness and its reduction following the microabrasion procedure can help to associate this alteration with the color changes. Another important limitation of study was that the specimens were stored in distilled water instead artificial saliva after the enamel microabrasion and tooth bleaching procedures. Both enamel microabrasion and tooth bleaching are able to increase the surface roughness due to acid $\mathrm{pH}$ of slurry ( $\mathrm{pH}$ of Opalustre is around 0.2 ) and bleaching agent ( $\mathrm{pH}$ of Whiteness HP Maxx range from 5.6 to 6$)$ used in the present study $(19,28)$. Considering that changes on surface roughness can modify the light reflection and color measurement, mainly related to lightness parameter, enamel remineralizing by specimens storage in artificial saliva could to reduce any possible bias related to methodology. Thus, further studies seeking out to turn these reported limitations might be required to confirm the findings of the present study.

\section{Resumo}

0 objetivo deste estudo foi avaliar o efeito da microabrasão prévia na alteração de cor dos dentes e na efetividade do clareamento dental. Oito molares hígidos foram mesio-distalmente seccionados e as metades foram aleatoriamente alocadas para receberem microabrasão do esmalte ou nenhuma abrasão (controle) em uma das faces (vestibular ou lingual), enquanto que a face remanescente recebeu o outro tratamento. A cor inicial dos dentes foi avaliada com um espectrofotômetro (sistema CieL*a*b). Após o procedimento de microabrasão, a cor do dente foi reavaliada. Em seguida, as amostras foram clareadas com peróxido de hidrogênio a 35\% por duas sessões com uma semana de intervalo. A cor foi reavaliada 7 dias após cada sessão e 30 dias após a segunda sessão. 0 efeito da microabrasão do esmalte na mudança de cor foi avaliado pelo teste T pareado. Deltas $L^{*}, \mathrm{a}^{*}, \mathrm{~b}^{*}$ e E foram calculados e os dados submetidos a ANOVA de duas vias para medidas repetidas e teste de Tukey. Teste T pareado também foi usado para verificar possiveis diferenças na cor final alcançada com o clareamento dental. A microabrasão do esmalte reduziu a luminosidade e aumentou a tonalidade vermelha nas amostras. Amostras submetidas a microabrasão apresentaram maiores valores de $\Delta \mathrm{L}^{*}$ que o controle após cada procedimento clareador, e maior $\Delta \mathrm{a}^{*}$ após a $2^{\mathrm{a}}$ sessão de clareamento. Entretanto, a microabrasão prévia do esmalte não afetou os valores finais dos parâmetros de cor. Apesar da microabraão do esmalte ter alterado a cor dental, este procedimento não afetou os resultados finais alcançados com o clareamento dental usando alta concentração de peróxido de hidrogênio.

\section{References}

1. Chen YW, Raigrodski AJ. A conservative approach for treating young adult patients with porcelain laminate veneers. J Esthet Rest Dent 2008;20:223-236.

2. Meireles SS, Goettems ML, Dantas RV, Bona ÁD, Santos IS, Demarco FF. Changes in oral health related quality of life after dental bleaching in a double-blind randomized clinical trial. J Dent 2014;42:114-121.

3. Matis BA, Cochran MA, Eckert G. Review of the effectiveness of various tooth whitening systems. Oper Dent 2009;34:230-235.

4. Rezende $M$, Loguercio $A D$, Kossatz $S$, Reis A. Predictive factors on the efficacy and risk/intensity of tooth sensitivity of dental bleaching: $A$ multi regression and logistic analysis. J Dent 2016;45:1-6.

5. de Geus JL, Wambier LM, Kossatz S, Loguercio AD, Reis A. At-home vs In-office Bleaching: A Systematic Review and Meta-analysis. Oper Dent 2016;41:341-356.

6. Eimar H, Siciliano R, Abdallah MN, Nader SA, Amin WM, Martinez PP, et al. Hydrogen peroxide whitens teeth by oxidizing the organic structure. J Dent 2012; Suppl 2:25-33.

7. Kwon SR, Wertz PW. Review of the Mechanism of Tooth Whitening. J Esthet Rest Dent 2015;27:240-57.

8. Shanbhag R, Veena R, Nanjannawar G, Patil J, Hugar S, Vagrali H. Use of clinical bleaching with $35 \%$ hydrogen peroxide in esthetic improvement of fluorotic human incisors in vivo. J Contemp Dent Pract. 2013;14:208-216.

9. Wallace A, Deery C. Management of Opacities in Children and Adolescents. Dent Update 2015;42:951-954, 957-978.

10. Carvalho LD, Bernardon JK, Bruzi G, Andrada MA, Vieira LC.Hypoplastic enamel treatment in permanent anterior teeth of a child. Oper Dent 2013;38:363-368.

11. Vasconcelos MQ, Vieira KA, Salgueiro MC, Alfaya TA, Ferreira CS, Bussadori SK. Microabrasion: a treatment option for white spots. J Clin Pediatr Dent 2014;39:27-29. 
12. Pini NI, Sundfeld-Neto D, Aguiar FH, Sundfeld RH, Martins LR, Lovadino $J R$, et al. Enamel microabrasion: An overview of clinical and scientific considerations. World J Clin Cases 2015;3:34-41.

13. Castro KS, Ferreira AC, Duarte RM, Sampaio FC, Meireles SS. Acceptability, efficacy and safety of two treatment protocols for dental fluorosis: a randomized clinical trial. J Dent 2014;42:938-944.

14. Villarroel M, FahI N, De Sousa AM, De Oliveira OB Jr. Direct esthetic restorations based on translucency and opacity of composite resins. J Esthet Rest Dent 2011;23:73-87.

15. Sundfeld RH, Rahal V, de Alexandre RS, Briso AL, Sundfeld Neto D. Smile restoration through use of enamel microabrasion associated with tooth bleaching. Compend Contin Educ Dent 2011;32:e-53-e57.

16. Franco LM, Machado LS, Salomão FM, Dos Santos PH, Briso AL, Sundfeld RH. Surface effects after a combination of dental bleaching and enamel microabrasion: An in vitro and in situ study. Dent Mater J 2016;35:13-20.

17. Kugel G, Petkevis J, Gurgan S, Doherty E. Separate whitening effects on enamel and dentin after fourteen days. J Endod 2007;33:34-37.

18. Ma X, Li R, Sa Y, Liang S, Sun L, Jiang T, Wang Y. Separate contribution of enamel and dentine to overall tooth colour change in tooth bleaching. J Dent 2011;39:739-745.

19. Paic M, Sener B, Schug J, Schmidlin PR. Effects of microabrasion on substance loss, surface roughness, and colorimetric changes on enamel in vitro. Quintessence Int 2008;39:517-522.

20. Dahl JE, Pallesen U. Tooth bleaching - a critical review of the biological aspects. Crit Rev Oral Biol Med 2003;14:292-304.

21. Goldberg M, Grootveld $M$, Lynch E. Undesirable and adverse effects of tooth-whitening products: a review. Clin Oral Invest 2010;14:1-10.
22. Paula $A B$, Dias MI, Ferreira MM, Carrilho $T$, Marto $C M$, Casalta J, et al. Effects on gastric mucosa induced by dental bleaching - an experimental study with 6\% hydrogen peroxide in rats. J Appl Oral Sci 2015;23:497-507.

23. Torres CR, Guimarães CA, Ribeiro ZE, Borges AB. Influence of Different Types and Concentrations of Chemical Catalysts on Dental Bleaching Efficiency. J Contemp Dent Pract 2015;16:893-902.

24. Moghadam FV, Majidinia S, Chasteen J, Ghavamnasiri M. The degree of color change, rebound effect and sensitivity of bleached teeth associated with at-home and power bleaching techniques: A randomized clinical trial. Eur J Dent 2013;7:405-411.

25. Freire $A$, Durski MT, Ingberman $M$, Nakao LS, Souza EM, Vieira S. Assessing the use of 35 percent sodium ascorbate for removal of residual hydrogen peroxide after in-office tooth bleaching. J Am Dent Assoc 2011;142:836-841.

26. Briso AL, Rahal V, Sundfeld RH, dos Santos PH, Alexandre RS. Effect of sodium ascorbate on dentin bonding after two bleaching techniques. Oper Dent 2014:39:195-203.

27. Borges AB, Batista GR, Arantes PT, Wiegand A, Attin T, Torres CR. Influence of simulated pulpal pressure on efficacy of bleaching gels. J Contemp Dent Pract 2014;15:407-12.

28. Trentino AC, Soares AF, Duarte MA, Ishikiriama SK, Mondelli RF. Evaluation of $\mathrm{pH}$ Levels and Surface Roughness After Bleaching and Abrasion Tests of Eight Commercial Products. Photomed Laser Surg 2015;33:372-377.

Received January 13, 2017 Accepted May 22, 2017 